\title{
Adsorption of Nickel and Cadmium by Corn Cob Biomass Chemically Modified with Alumina Nanoparticles
}

\author{
A. Herrera-Barros' ${ }^{1}$ C. Tejada-Tovar², A. Villabona-Ortiz², A. D. Gonzalez-Delgado ${ }^{1 *}$ and \\ J. Alvarez-Calderon ${ }^{1}$ \\ 'Department of Chemical Engineering, Nanomaterials and Computer Aided Process Engineering Research Group \\ (NIPAC), University of Cartagena, Cartagena, Bolivar, Colombia; \\ aherrerab@unicartagena.edu.co,agonzalezd1@unicartagena.edu.co, jalvarezc@unicartagena.edu.co \\ 2Department of Chemical Engineering, Process Design and Biomass Utilization Research Group (IDAB), University of \\ Cartagena, Cartagena, Bolivar, Colombia; \\ ctejadat@unicartagena.edu.co, avillabonao@unicartagena.edu.co
}

\begin{abstract}
Background: In recent decades, agricultural residues have been widely applied in the development of novel materials in order to obtain high-value products and reduce disposal issues. Objectives: In this work, corn cob residual biomass was used to prepare a biosorbent chemically modified with alumina nanoparticles. Methods/Analysis: The alumina nanoparticles were synthesized by sol-gel methodology and loaded into biomass matrix using an organic solvent. The corn cob biomass was characterized by ultimate analysis, FT-IR technique, Boehm titration and point of zero charges method, which provide information related charge of biomass surface, diversification of functional groups and elemental composition. SEM and EDX analyses were also performed in order to study morphology and composition of the prepared biosorbent. Batch adsorption experiments were carried out to evaluate the effect of $\mathrm{pH}$ and particle size on adsorption efficiency and determine suitable conditions for further experimentation. Findings: The physicochemical characterization of corn cob biomass revealed the presence of carboxyl, hydroxyl and amine functional groups in FT-IR spectrum. After loading alumina nanoparticles, this spectrum exhibited characteristic peaks of aluminum bonds suggesting a successful synthesis. In addition, it was observed that $\mathrm{pH}$ played an important role in removal yield results, hence, $\mathrm{pH}=6$ were selected as suitable value for performing further experiments. The removal yield for cadmium and nickel ions using chemically modified biomass were 91 and 86\%, respectively, results higher than those obtained using biomass. Novelty/Improvement: The modification with Al203 nanoparticles enhances adsorption process and could be applied to other sources of biomass.
\end{abstract}

Keywords: Agricultural Residues, Alumina Nanoparticle, Biosorbent, Removal Yield

\section{Introduction}

The agricultural activities generate a lot of wastes that are being an environmental problems related to the disposal.
Hence, researchers have studied different alternatives for converting agricultural residues into high-value products ${ }^{1}$. These lignocellulosic biomasses are one of the most widely used and low-cost biosorbent in the adsorption

${ }^{*}$ Author for correspondence 
process of heavy metal ions ${ }^{2}$. The application of biosorbents for heavy metals uptake seems to be more suitable because of the following advantages: low operating cost, selectivity, abundant availability, high removal yield and environmental friendly $\underline{3}$. Several biosorbents have been prepared from agricultural biomasses such as: rice straw, orange peels, pecan nut husk, corn cob, among others ${ }^{4}$. Corn (Zeamays) is considered one of the major crops that grow worldwide and is included in nutritional diet $^{5}$. The main residues from corn processing activities are husk, silk, leaves and cob, which have been received great attention for developing novel biomaterials with a wide variety of applications. Used corn cob for chromium uptake and obtained removal yields around 39.8\% at $\mathrm{pH}$ solution of 2 and particle size of $0.355 \mathrm{~mm}$. On the other hand, nanotechnology offers methodologies to modify residual biomasses in order to improve their performance in adsorption process due to the increase of surface area ${ }^{6}$. Among these, loading magnetic nanoparticles into biomass matrix as titanium dioxide, alumina, cerium oxide and zinc oxide provides an enhancement of physicochemical properties of biomaterials ${ }^{\mathrm{z}}$. In this work, corn cob biomass and alumina nanoparticles were used to prepare a biosorbent useful to remove cadmium and nickel ions, which are discharged to the environment by industrial sectors including metal plating facilities, battery manufacturing and mining.

\section{Material and Methods}

\subsection{Biomass Preparation}

The cultivation of corn crop generates several residues that can be used as lignocellulosic biomass. In this framework, corn cob residues were selected to prepare a novel biosorbent. This agricultural biomass was purchased from a local farm and washed thoroughly to remove impurities. Then, the cleaned biomass was dried, grounded and sieve-meshed according to that reported by $\stackrel{8}{.}$

\subsection{Synthesis of Nanoparticles}

The sol-gel methodology is recognized to increase porous size providing high surface area for heavy metal ions uptake. The alumina nanoparticles synthesis was based on the work performed by ${ }^{9}$, in which $0.5 \mathrm{M}$ (Al $\left.\left(\mathrm{NO}_{3}\right)_{3} \cdot 9 \mathrm{H}_{2} \mathrm{O}\right)$ solution was mixed with 0.5 moles of citric acid $\left(\mathrm{C}_{6} \mathrm{H}_{8} \mathrm{O}_{7}\right)$ solution. The resulting mixture was continuously stirred at $60^{\circ} \mathrm{C}$ until a yellow pigmentation appeared. The temperature was increased in $20^{\circ} \mathrm{C}$ to form a gel that was heated at $750^{\circ} \mathrm{C}$ in order to obtain powder of alumina nanoparticles.

\subsection{Biomass Modification with Alumina Nanoparticles}

The novel biosorbent was prepared by loading $\mathrm{Al}_{2} \mathrm{O}_{3}$ nanoparticles into corn cob biomass and dimethyl sulfoxide (DMSO) was used as organic solvent. In brief, 0.5 of biomass was added to DMSO solution in order to form a suspension after stirring for $24 \mathrm{~h}$. Afterward, tetra ethyl-osilicate (TEOS) and powder of nanoparticles were added to this suspension. The prepared biosorbent was washed with ethanol to remove soluble impurities $\frac{10,11}{}$.

\subsection{Characterization Techniques}

As is summarized in Table 1, several characterization techniques were applied to determine physicochemical properties of the resulting biosorbent as well as the alumina nanoparticles and biomass.

The elemental composition of corn cob biomass was determined by ultimate analysis. The diversification of functional groups was identified by Fourier Transform Infrared Spectroscopy (FT-IR) before and after loading alumina nanoparticles into the biomass. Boehmtitration was used to quantify the amount of lactonic, phenolic and carboxylic components in corn cob biomass. In addition, a scanning electron microscope (SEM) coupled to an energy-dispersive X-ray spectroscope (EDS) was used to observe morphology of nanomaterials and confirm its elemental composition. 
Table 1. Methods of biosorbent characterization

\begin{tabular}{|c|c|}
\hline Parameter & Method \\
\hline Carbon (\%) & AOAC 949.14 \\
\hline Hydrogen (\%) & AOAC 949.14 \\
\hline Nitrogen (\%) & AOAC 984.13 KJELDAHL \\
\hline Ashes (\%) & Thermogravimetry \\
\hline Pectin (\%) & Digestion-thermogravimetry \\
\hline Lignin (\%) & Photocalorimetry \\
\hline Cellulose (\%) & Digestion-thermogravimetry \\
\hline Hemicellulose (\%) & Digestion-thermogravimetry \\
\hline Functional groups & Fö-IR \\
\hline Lactonic, phenolic and carboxylic components & Bitration \\
\hline
\end{tabular}

\subsection{Determination of Point of Zero Charges}

The point of zero charges $\left(\mathrm{pH}_{\mathrm{PZC}}\right)$ has been widely calculated for biomasses because it provides information about suitable values of $\mathrm{pH}$ solution. In brief, $0.5 \mathrm{~g}$ of corn cob biomass was mixed with $50 \mathrm{~mL}$ of distillate water and stirred for 48 hours. The solution $\mathrm{pH}$ was measured before and after this procedure. It was expected changes in surface charge of biomass due to the adsorption of $\mathrm{H}^{+}$ or $\mathrm{OH}^{-i o n s}{ }^{12}$.

\subsection{Biosorption Study}

Stock solutions of nickel and cadmium were prepared by dissolving nickel sulfate $\left(\mathrm{NiSO}_{4}\right)$ and cadmium sulfate $\left(\mathrm{CdSO}_{4}\right)$ in deionized water until achieving a solution concentration of $100 \mathrm{ppm}$. The parameter of temperature, contact time and dosage of biosorbent were fixed in all batch experiments. Solution $\mathrm{pH}$ as well as particle size was varied in order to analysis its effects on adsorption process. The $\mathrm{pH}$ was adjusted to 2,4 and 6 by adding $\mathrm{HCl}$ and $\mathrm{NaOH}$. Three different particle sizes were considered for this purpose $(0.355,0.5$ and $1 \mathrm{~mm})$. The remaining concentration of cadmium and nickel was determined using diphenylcarbazide acid solution and a UV/Vis Shimdzu UV 1700 spectrometer. The mathematical expression of removal yield is described in Equation 1.

Removal yield $(\%)=\frac{\left(C_{o}-C_{e}\right)}{C_{o}} 100 \%$

\section{Results and Discussion}

\subsection{Characterization of Residual Biomass}

The composition of corn cob biomass is summarized in Table 2, in which carbon element most contributes with $39.89 \%$ of dried biomass. This result was expected due to the organic nature of the agroindustrial residue. The composition of cellulose, lignin, hemicellulose and pectin reported to be 13.08, 6.51, 6.47 and 7.98 (wt. \%) respectively. 
Table 2. Composition of corn cob biomass

\begin{tabular}{|c|c|}
\hline Parameter & Value \\
\hline Carbon (\%) & $39.89 \pm 0.41$ \\
\hline Hydrogen (\%) & $3.28 \pm 0.09$ \\
\hline Nitrogen (\%) & $0.46 \pm 0.04$ \\
\hline Sulfur (ppm) & $0.28 \pm 0.10$ \\
\hline Ashes (\%) & $1.20 \pm 0.08$ \\
\hline Pectin (\%) & $7.98 \pm 0.33$ \\
\hline Lignin (\%) & $6.51 \pm 0.18$ \\
\hline Cellulose (\%) & $13.08 \pm 0.25$ \\
\hline Hemicellulose (\%) & $6.47 \pm 0.07$ \\
\hline
\end{tabular}

FT-IR analysis was carried out to identify the presence of functional groups as hydroxyl, carboxyl and amines, which are recognized to improve adsorption process. As is shown in Figure 1, hydroxyl stretching vibrations were observed around $3314.67 \mathrm{~cm}^{-1}$. Lignocellulosic materials are characterized to have carboxyl groups that were

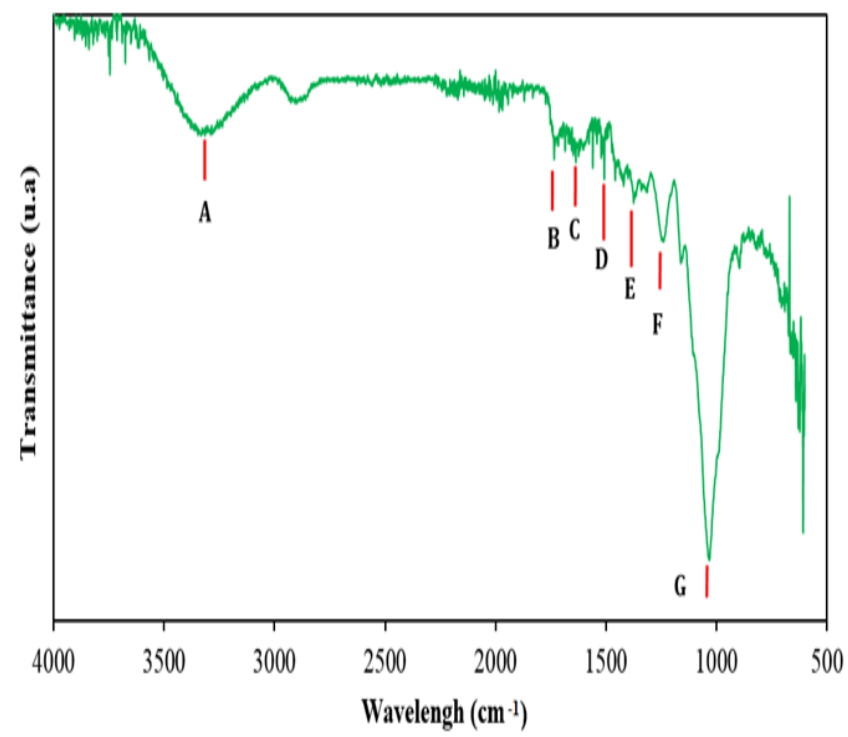

Figure 1. FT-IR spectrum of corn cob biomass. observed around $1733.7 \mathrm{~cm}^{-1}$. The absorption band at $1031.79 \mathrm{~cm}^{-1}$ was assigned to primary alcohols $(\mathrm{C}-\mathrm{OH})$. The complete diversification of functional groups is listed in Table 3. These functional groups characteristic of biomass were also observed after loading alumina

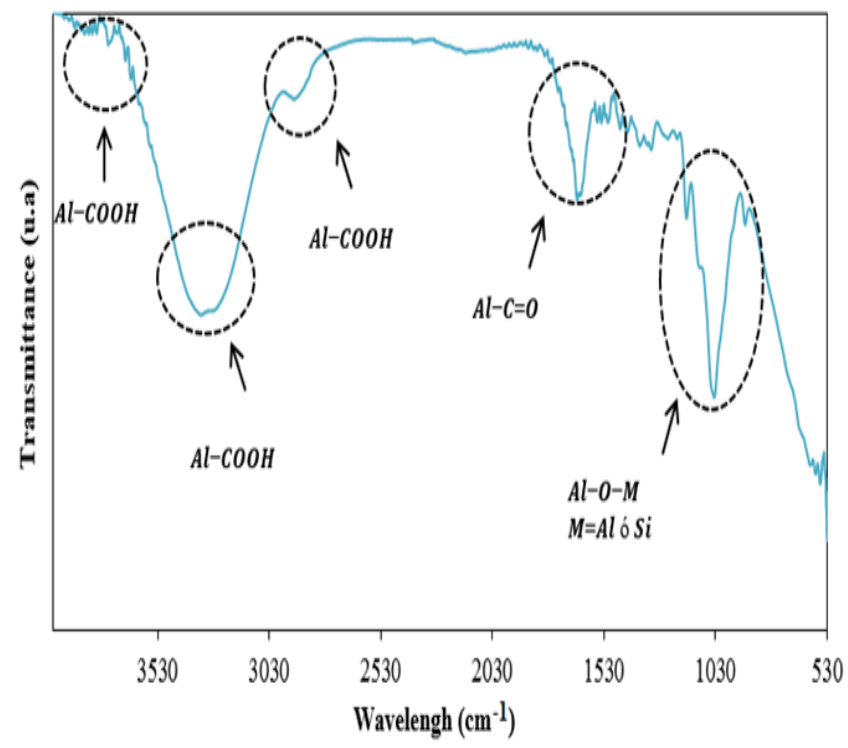

Figure 2. FT-IR spectrum of chemically modified biomass with $\mathrm{Al}_{2} \mathrm{O}_{3}$ nanoparticles. 
Table 3. Characteristic absorption bands in FT-IR spectrum of biomass

\begin{tabular}{|c|c|c|c|}
\hline Band & Wavelength $\left(\mathrm{cm}^{-1}\right)$ & Functional group & Bond \\
\hline A & 3314.67 & Alcohol and phenols & \\
\hline B & 1733.70 & Aldehydes, ketones and carboxylic acid & \\
\hline C & 1635.44 & Alkenes & \\
\hline D & 1506.79 & Secondary amines & \\
\hline E & 1374.08 & Alkanes & \\
\hline F & 1238.28 & Amides & \\
\hline G & 1031.79 & Primary alcohol & \\
\hline
\end{tabular}

$\operatorname{In} \underline{14}$

nanoparticles. Figure 2 shows the FT-IR spectrum of the resulting biosorbent which presents adsorption peaks of aluminum oxide. The bands at 700, 1034 and 3292 $\mathrm{cm}^{-1}$ are assigned to $\mathrm{Al}-\mathrm{O}-\mathrm{Al}, \mathrm{Al}-\mathrm{C}=\mathrm{O}$ and $\mathrm{Al}-\mathrm{COOH}$ stretching vibrations, respectively ${ }^{\underline{13}}$. The presence of these bonds with aluminium suggested a successful synthesis

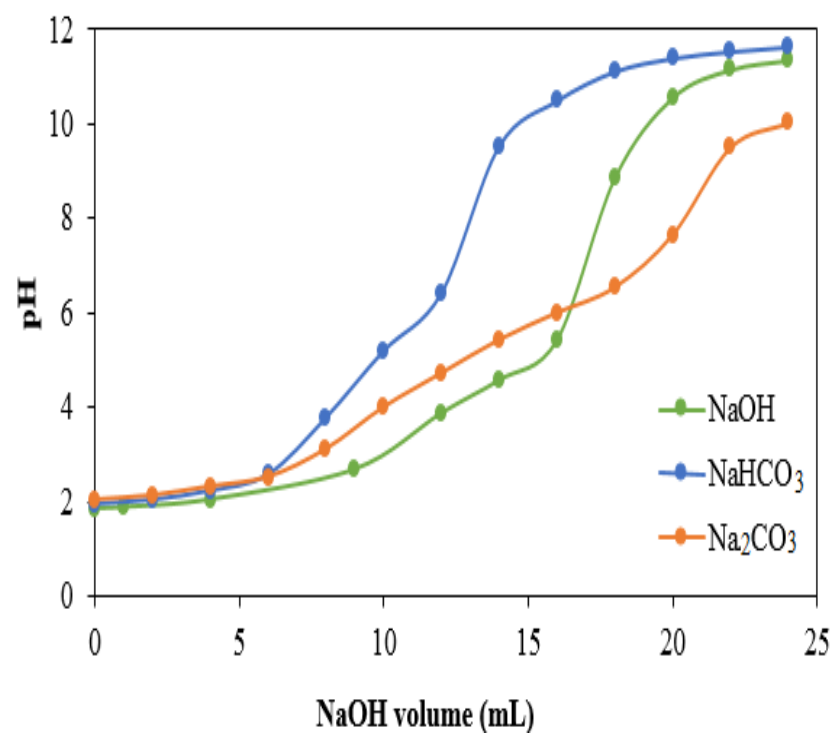

Figure 3. The $\mathrm{pH}$ curve during titration methodology for corn cob biomass. of biosorbent due to the incorporation of aluminium and oxygen in biomass.

The measurement of carboxylic, lactonic and phenolic components was performed by Boehm titration. It was found 3306, 18890 and $0 \mu$ moles of carboxylic, lactonic and phenolic components, respectively, suggesting that corn cob biomass could interact with heavy metal ions due to the active functional groups. As shown in Figure 3, the $\mathrm{pH}$ curve was constructed to calculate the equivalent point as well as the requirements of sodium hydroxide to perform Boehmmethodology $y^{15}$.

SEM and EDX Analysis: Figure 4 shows the results for both SEM and EDS analyses carried out to identify morphology and elemental composition of chemically modified biomass, respectively. As is observed from SEM micrograph, the biosorbent exhibits a porous surface with aggregations that suggested the formation of alumina amorphous phase. This porous structure indicates that physical adsorption process plays a substantial role on biosorption of biosorbents $\frac{16}{}$. In addition, EDX spectrum revealed that carbon, oxygen and aluminium are the elements that most contribute to biosorbent composition as follows: C (wt \%) 44.01, O (wt \%) 47.31, Al (wt \%) 7.00 and $\mathrm{Si}($ wt \%) 1.68 . 

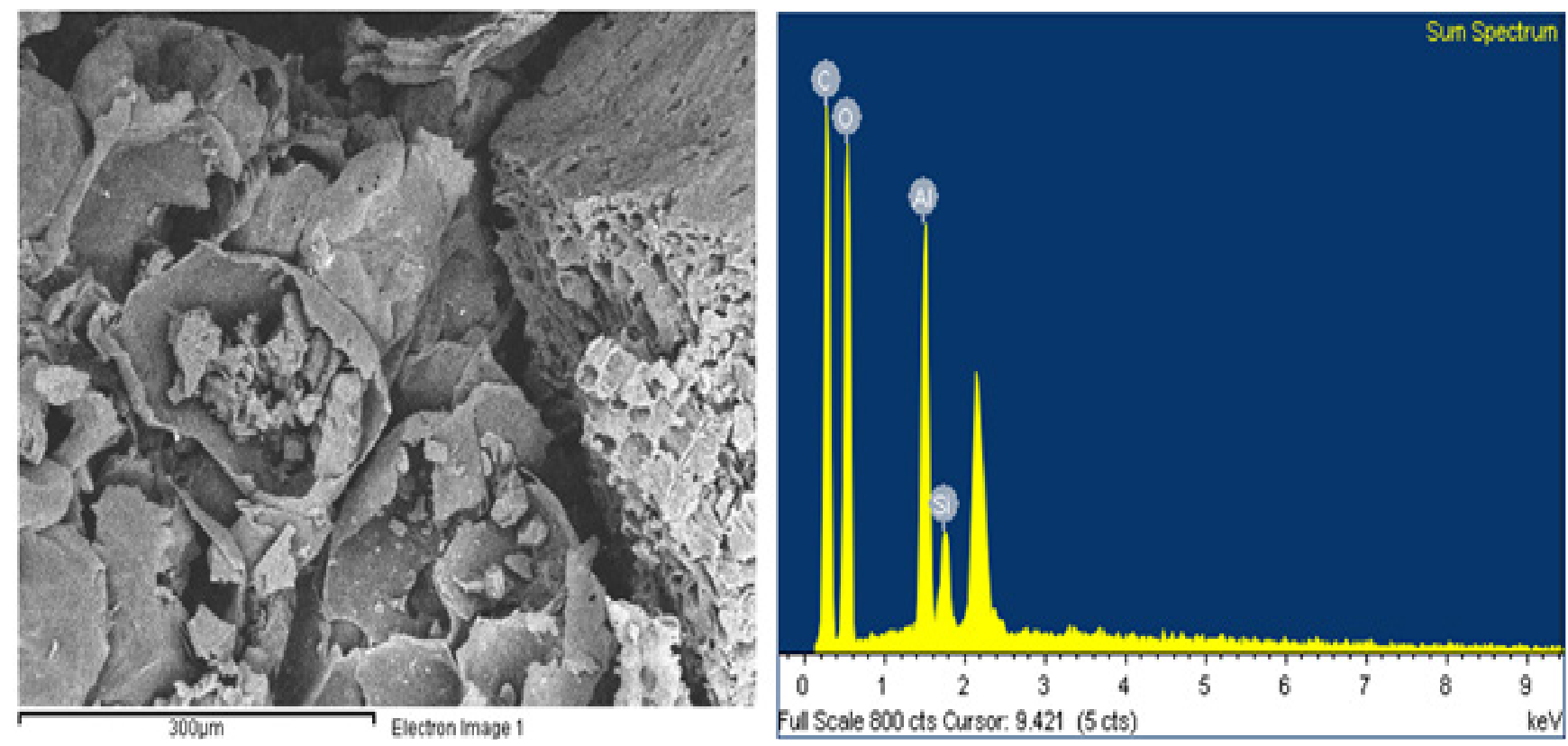

Figure 4. SEM and EDS analyses for chemically modified corn cob biomass.

\subsection{Determination of Point of Zero Charges}

The point of zero charges of adsorbents is an important parameter that determines the $\mathrm{pH}$ value at which the surface exhibits net electrical neutrality $\frac{17}{}$. For $\mathrm{pH}$ values higher than $\mathrm{pH}_{\mathrm{pzc}}$, the biosorbent surface has negative

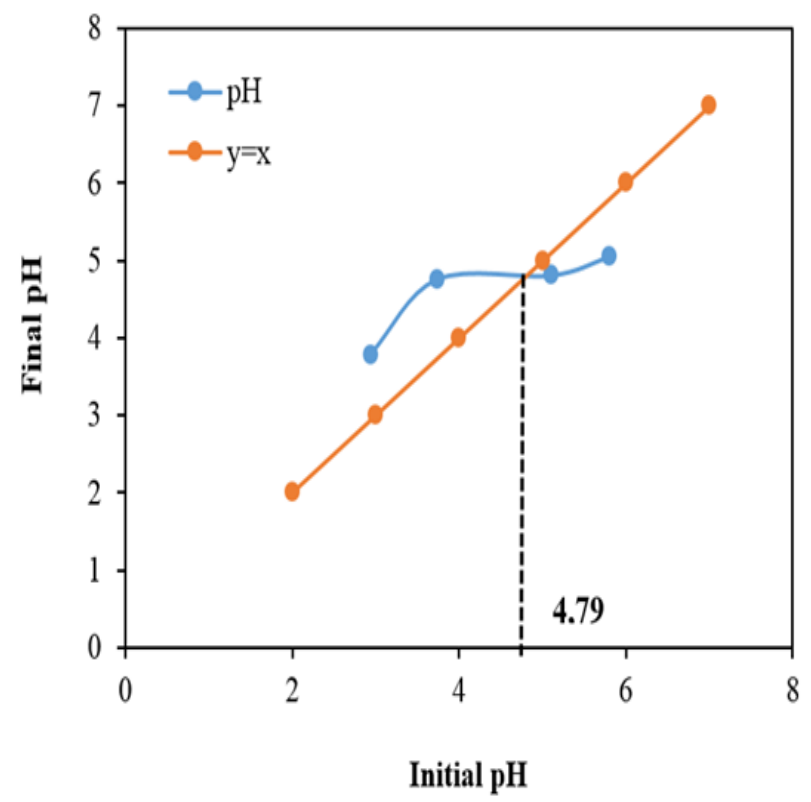

Figure 5. Point of zero charges for corn cob biomass. charge that induces a strong attraction forces. As shown in Figure 5, the curve cuts $\mathrm{pH}_{\text {final }}=\mathrm{pH}_{\text {initial }}$ at 4.79 for corn cob biomass ${ }^{18}$. Determined the point of zero charges for raw corn cob as 6.2 .

\subsection{Bioadsorption Study}

The results on the effect of particle size and solution $\mathrm{pH}$ are shown in Figures 6-7 for cadmium and nickel, respectively. As can be observed, the removal yield was not significantly affected by the decrease in particle size. It is well known that a decrease in particle size increases the accessibility to the particles pores, however, particle diameter below $0.5 \mathrm{~mm}$ could affect adsorption efficiency due to the suspension of finer particles in the aqueous solution $\frac{19}{}$. The solution $\mathrm{pH}$ was considered an important operating parameter because its influence in sorption affinity by either altering the biosorbent surface properties and the ionic form of heavy metal ions $s^{20}$. The removal yields in $\mathrm{pH}$ range 1-4 were similar suggesting that saturation of active sites occur at $\mathrm{pH}=4^{21}$. It was expected high adsorption efficiency in this range because of the value of point of zero charges of corn cob biomass. In addition, Pareto chart in Figure 8 confirms that $\mathrm{pH}$ solution param- 


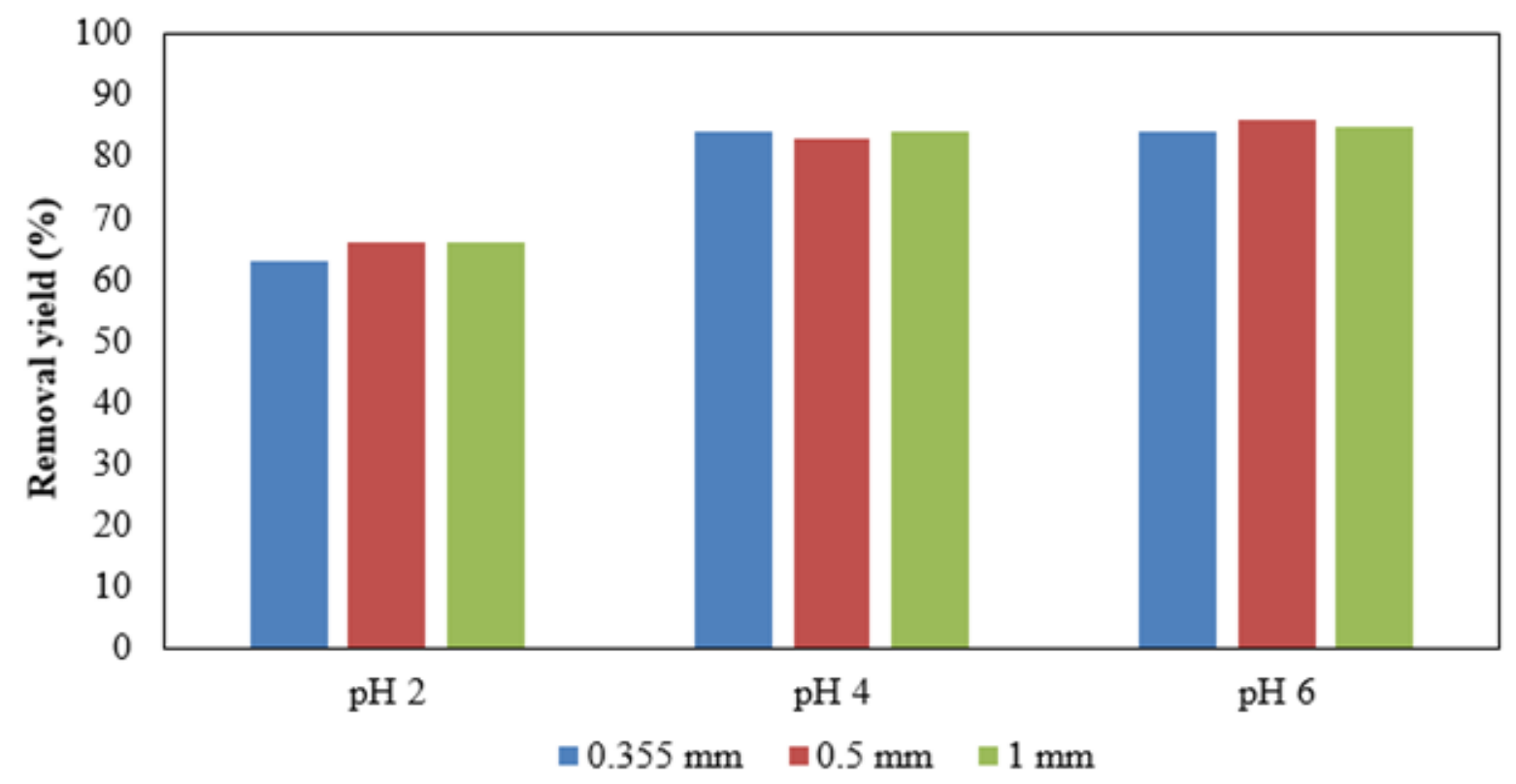

Figure 6. Effect of particle size and $\mathrm{pH}$ on removal yield of $\mathrm{Cd}$ (II) ions using corn cob biomass.

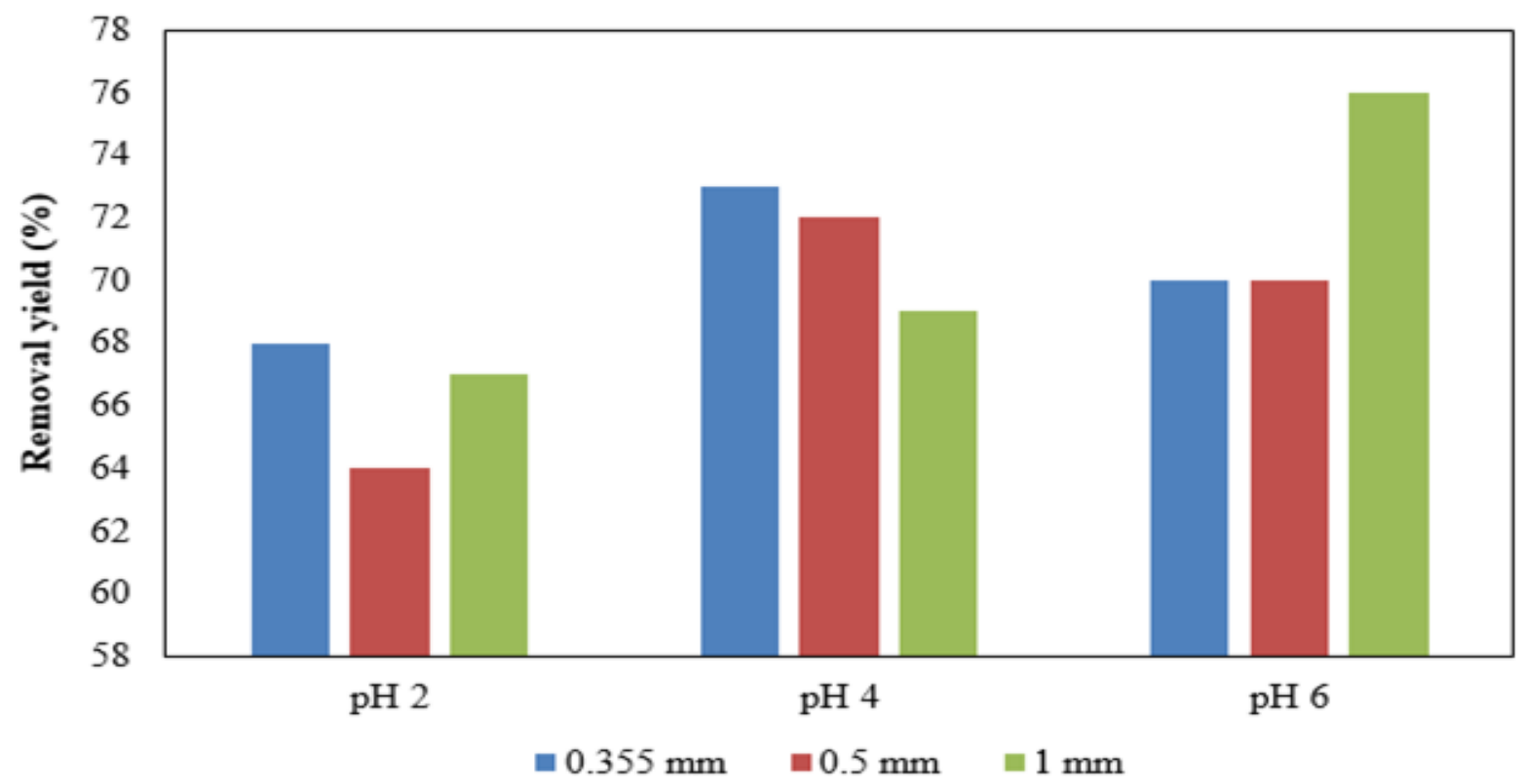

Figure 7. Effect of particle size and $\mathrm{pH}$ on removal yield of $\mathrm{Ni}$ (II) ions using corn cob biomass.

eter plays a more important role in adsorption process than particle size.

The highest removal yield for cadmium ions was calculated in $86 \%$ using particle size of $0.5 \mathrm{~mm}$ and $\mathrm{pH}$ solution of 6 . For nickel ions, the highest adsorption efficiency $(76 \%)$ was achieved at $\mathrm{pH}$ solution of 6 and particle size of $1 \mathrm{~mm}$. According to that reported by 22 , it was expected that corn cob biomass exhibited higher selectiv- 

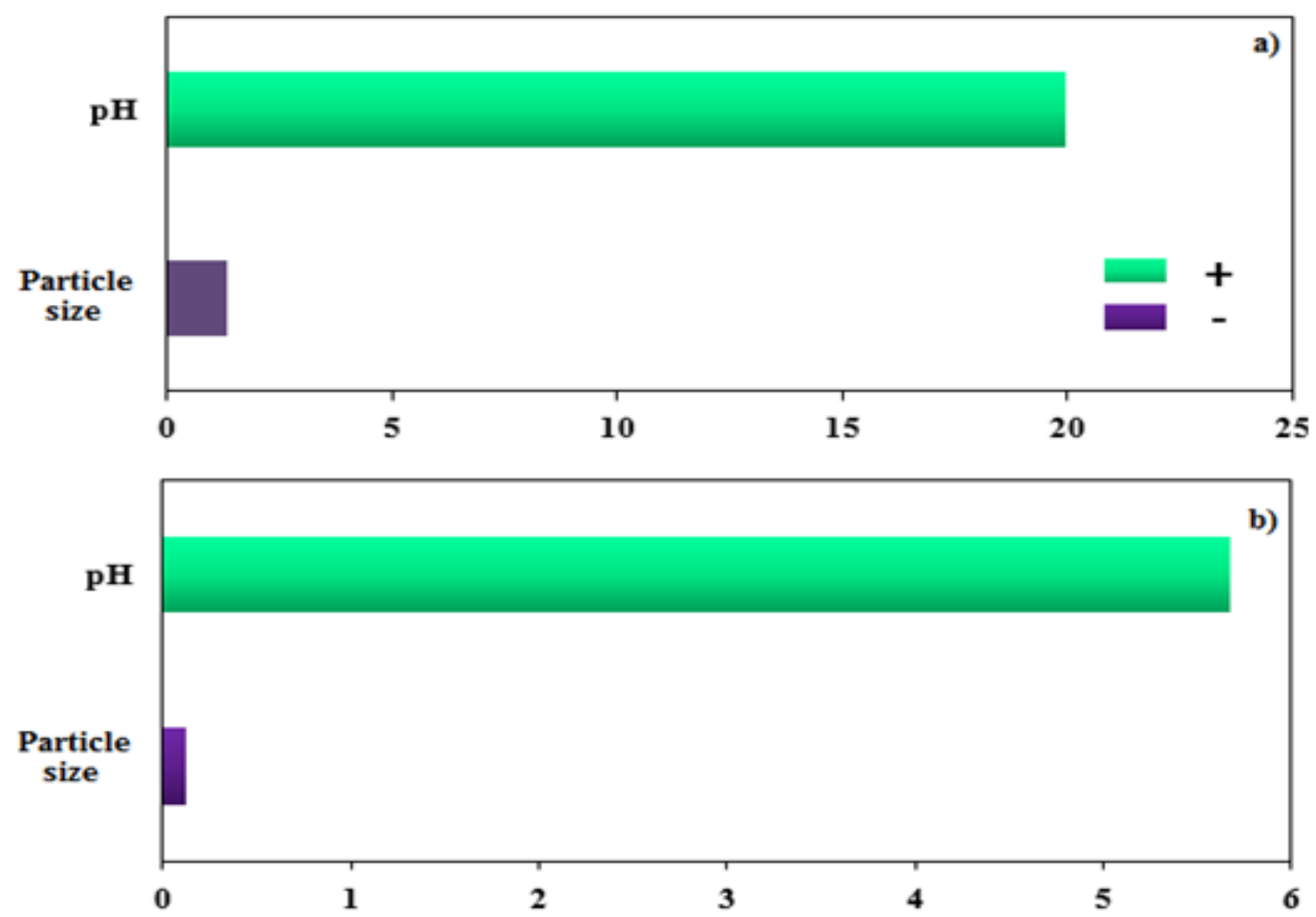

Figure 8. Pareto chart for: a) cadmium and b) nickel removal yields using corn cob biomass.

Table 4. A summary of biomasses used in cadmium ions uptake

\begin{tabular}{|c|c|c|c|c|c|c|}
\hline Biomass & $\begin{array}{c}\text { Removal yield } \\
(\%)\end{array}$ & $\mathbf{p H}$ & $\begin{array}{c}\text { Particle size } \\
(\mathbf{m m})\end{array}$ & Dosage (g/L) & $\mathbf{T}\left({ }^{\circ} \mathbf{C}\right)$ & Reference \\
\hline Zea Mays powder & 79.36 & 6.5 & 0.105 & 10 & 25 & $\operatorname{In}^{23}$ \\
\hline $\begin{array}{c}\text { Commercial activated } \\
\text { carbon }\end{array}$ & 83.00 & 5.7 & - & 2.5 & - & $\operatorname{In}^{24}$ \\
\hline Pomelo powder & 85.94 & 4.5 & 0.25 & 5 & 25 & $\operatorname{In}^{25}$ \\
\hline Corn cob & 86.00 & 6 & 0.355 & 5 & 25 & $\operatorname{This~work~}^{25}$ \\
\hline
\end{tabular}

ity for cadmium ions than nickel ions explained by larger ions could better fit a binding site. Similar removal yields results were reported in other works using different biomasses as is summarized in Tables 4-5.
The resulting biosorbent after chemical modification with alumina nanoparticles was also used to nickel and cadmium uptake under suitable conditions of $\mathrm{pH}$ and particle sizes (6 and $1 \mathrm{~mm}$, respectively). Figure 9 reveals 
Table 5. A summary of biomasses used in nickel ions uptake

\begin{tabular}{|c|c|c|c|c|c|c|}
\hline Biomass & $\begin{array}{c}\text { Removal } \\
\text { yield (\%) }\end{array}$ & $\mathbf{p H}$ & $\begin{array}{c}\text { Particle size } \\
(\mathbf{m m})\end{array}$ & Dosage $(\mathbf{g} / \mathbf{L})$ & $\mathbf{T}\left({ }^{\circ} \mathbf{C}\right)$ & Reference \\
\hline Rice husk & 65.40 & 6 & - & $20 \mathrm{~g} / \mathrm{L}$ & $55^{\circ} \mathrm{C}$ & $\operatorname{In}^{26}$ \\
\hline Sugarcane bagasse & 78.00 & 7.5 & - & $1.5 \mathrm{~g} / \mathrm{L}$ & $25^{\circ} \mathrm{C}$ & $\operatorname{In}^{27}$ \\
\hline Zea Mays powder & 71.98 & 6.5 & $0.105 \mathrm{~mm}$ & $10 \mathrm{~g} / \mathrm{L}$ & $25^{\circ} \mathrm{C}$ & $\operatorname{In}^{23}$ \\
\hline Corn cob & 76.00 & 6 & $0.355 \mathrm{~mm}$ & $5 \mathrm{~g} / \mathrm{L}$ & $25^{\circ} \mathrm{C}$ & $T_{\text {This work }}$ \\
\hline
\end{tabular}

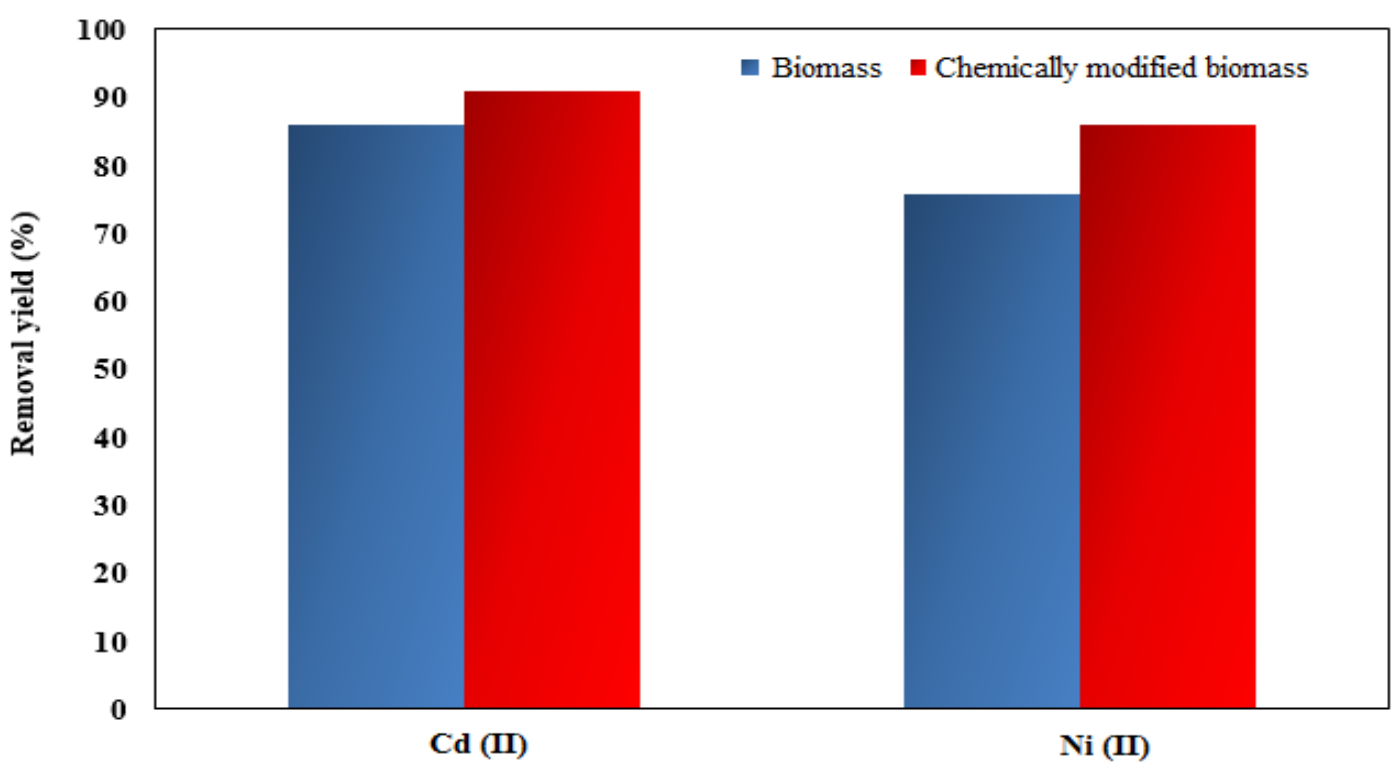

Figure 9. Comparison of removal yields using biomass and chemically modified biomass.

that chemically modified biomass exhibited highest removal yields than biomass indicating an enhancement in adsorption process after loading alumina nanoparticles into corn cob biomass. The removal yields for cadmium and nickel ions using chemically modified biomass were 91 and $86 \%$, respectively.

\section{Conclusions}

This work attempted to apply a novel biosorbent prepared from corn cob biomass and alumina nanoparticle for removing cadmium and nickel from aqueous solution. The physicochemical characterization of this biomass revealed the presence of carboxyl, hydroxyl and amide groups which positively contributes to adsorption process. As was expected due to the lignocellulosic nature of corn cob, carbon most contributed biomass composition. The carboxylic, lactonic and phenolic components were quantified in 3306, 18890 and $0 \mu$ moles, respectively. SEM micrograph revealed a porous structure useful for 
adsorption process and EDX spectrum confirmed that carbon, oxygen and aluminum are present in the prepared biosorbent. The batch adsorption experimental results allowed determining as suitable conditions the $\mathrm{pH}$ solution of 6 and particle size of $1 \mathrm{~mm}$. The removal yield for cadmium and nickel ions using chemically modified biomass were 91 and $86 \%$, respectively, results higher than those obtained using raw biomass indicating that modification with alumina nanoparticles enhanced adsorption process.

\section{Acknowledgments}

The authors express their gratitude to COLCIENCIAS and University of Cartagena for their support to develop this work.

\section{References}

1. Salakhum S, Yutthalekha T, Chareonpanich M, Limtraku J, Wattanakit C. Synthesis of hierarchical faujasite nanosheets from corn cob ash-derived nanosilica as efficient catalysts for hydrogenation of lignin-derived alkylphenols. Microporous and Mesoporous Materials. 2018; 258:141-50. Crossref.

2. Mahmoud M. Kinetics studies of uranium sorption by powdered corn cob in batch and fixed bed system. Journal of Advanced Research. 2016; 7(1):79-87. Crossref. PMid:26843973 PMCid:PMC4703490.

3. Kaur A, Sharma S. Removal of Heavy Metals from Waste Water by using Various Adsorbents-A Review. Indian Journal of Science and Technology. 2017; 10(34):1-14. Crossref.

4. Tovar TC, Barros HA, Ortiz VA, Delgado GA, Zarur NJ. Hexavalent Chromium Adsorption from Aqueous Solution Using Orange Peel Modified with Calcium Chloride: Equilibrium and Kinetics Study. Indian Journal of Science and Technology. 2018; 11(17):1-10.Crossref.

5. Cogollo CE, Ramos RY, Delgado OK. Evaluation of the Biogas Productivity Potential of Maize Waste Using Ruminal Fluid and Pig Manure. Contemporary Engineering Sciences. 2018; 11(7):307-15. Crossref.

6. Padmavathy K, Madhu G, Hassena P. A study on effects of $\mathrm{pH}$, adsorbent dosage, time, initial concentration and adsorption isotherm study for the removal of hexavalent chromium (Cr (VI)) from wastewater by magnetite nanoparticles. Procedia Technology. 2016; 24:585-94. Crossref.
7. Mathew J, Joy J, George SC. Potential applications of nanotechnology in transportation: A review. Journal of King Saud University - Science. 2018.

8. Bedoya PM, Tamayo CA. Caracterizacion de la cascara de naranja para suusocomo material bioadsorbente. Bistua. 2008; 6(1):1-23.

9. Li J, Pan Y, Xiang C, Ge Q, Guo J. Low temperature synthesis of ultrafine a-Al2O3 powder by a simple aqueous sol-gel process. Ceramics International. 2006; 32(5):587-91. Crossref.

10. Sadri M, Pedbeni A, Hossein H. Preparation of Biopolymeric Nanofiber Containing Silica and Antibiotic. Journal of Nanostructures. 2016; 6(1):96-100.

11. Mohseni M, Gilani K, Mortazavi SA. Preparation and Characterization of Rifampin Loaded Mesoporous Silica Nanoparticles as a Potential System for Pulmonary Drug Delivery. Iranian Journal of Pharmaceutical Research. 2015; 14(1):27-34. PMid:25561909 PMCid:PMC4277616

12. Alves V, Mosquetta R, Coelho N. Determination of cadmium in alcohol fuel using Moringa oleifera seeds as a biosorbent in an on-line system coupled to FAAS. Talanta. 2010; 80(3):1113-38. Crossref. PMid:20006064.

13. Carmona S. Elaboracion y caracterizacion de peliculasdelgadas de oxido de aluminio: propiedadesopticas, estructurales y electricas. Instituto politecniconacional Mexico DF. 2008; p. 1-112.

14. Skoog DA, Holler FJ, Nieman TA. Principios de analisis instrumental. Madrid McGraw-Hill. 2001; p. 122-50.

15. Oickle A, Goertzen S, Hopper K, Abdalla Y, Andreas H. Standardization of the Boehm titration: Part II. Method of agitation, effect of filtering and dilute titrant. Carbon. 2010; 48(12):3313-22. Crossref.

16. Vafakhah S, Bahrololoom M, Saeedikhani M. Removal of copper ions from electroplating effluent solutions with native corn cob and corn stalk and chemically modified corn stalk. Journal of Environmental Chemical Engineering. 2014; 2(1):356-61. Crossref.

17. Vafakhah S, Bahrololoom ME, Saeedikhani M. Adsorption Kinetics of Cupric Ions on Mixture of Modified Corn Stalk and Modified Tomato Waste. Journal of Water Resource and Protection. 2016; 8(13):1238-50. Crossref.

18. Ramos L, Jacome BL, Rodriguez AI. Adsorption of cadmium (II) from aqueous solution on natural and oxidized corn cob. Separation and Purification Technology. 2005; 45(1):41-9. Crossref.

19. Alves C, Franca A, Oliveira L. Removal of phenylalanine from aqueous solutions with thermo-chemically modified corn cobs as adsorbents. LWT - Food Science and Technology. 2013; 51(1):1-8. Crossref.

20. Sakulthaew C, Chokejaroenrat C, Poapolathep A. Hexavalent chromium adsorption from aqueous solution 
using carbon. Chemosphere. 2017; 184:1168-74. Crossref. PMid:28672698.

21. Gupta V, Nayak A. Cadmium removal and recovery from aqueous solutions by novel adsorbents prepared from orange peel and $\mathrm{Fe} 2 \mathrm{O} 3$ nanoparticles. Chemical Engineering Journal. 2012; 180:81-90. Crossref.

22. Figueira M, Volesky B, Ciminelli V, Roddick F. Biosorption of metals in brown seaweed biomass. Water Research. 2000; 34(1):196-204. Crossref.

23. Goyal P, Srivastava S. Characterization of novel Zeamays based biomaterial designed for toxic metals biosorption. Journal of Hazardous Materials. 2009; 172(2):1206-11. Crossref. PMid:19709812.

24. Basso M, Cukierman A. Empleo de un biosorbente para el tratamiento de agua. Avancesen Energias Renovables y Medio Ambiente. 2003; 7:901-6.
25. Rebollo J. Eliminacon de Cadmio (II) de efluentesurbanostratadosmedianteprocesos de bioadsorcion: El efectocompetitivo de otrosmetalespesados. 2012; p. 1-113.

26. Bansal M, Singh D, Garg V, Rose P. Use of Agricultural Waste for the Removal of Nickel Ions from Aqueous Solutions: Equilibrium and Kinetics Studies. World Academy of Science, Engineering and Technology. 2009; 3(3):1-27.

27. Garg U, Kaur M, Garg V, Sud D. Removal of Nickel (II) from aqueous solution by adsorption agricultural waste biomass using a response surface methodological approach. Bioresource Technology. 2008; 99(5):1325-31. Crossref. PMid:17383868. 